\title{
Tomato (Lycopersicum sculentum) production in sub surface flow constructed wetlands for domestic wastewater treatment in rural a colombian community \\ Producción de tomate (Lycopersicum sculentum) en un humedal construido de flujo sub superficial para el tratamiento de agua residual doméstica en una comunidad rural (Colombia)
}

Caselles-Osorio Aracelly

Centro de Estudios del Agua, Universidad del Atlántico

E-mail: aracellycaselles@mail.uniatlantico.edu.co

https//:orcid.org/0000-0001-9227-1606

Mendoza Gizek

Centro de Estudios del Agua, Universidad del Atlántico

E-mail: gicmendoza@hotmail.com

https//:orcid.org/0000-0002-1040-3458

Simanca Mayler

Centro de Estudios del Agua, Universidad del Atlántico

E-mail: maylersimanca07@hotmail.com

https//:orcid.org/0000-0002-2729-0234

\author{
Romero-Borja Isaac \\ Universidad del Magdalena, Santa Marta, Colombia \\ E-mail: iromero149@hotmail.com \\ https//:orcid.org/ 0000-0002-8409-1039 \\ Mosquera José Euliser \\ Research group, Humedales del Caribe Colombiano \\ Universidad del Atlántico \\ E-mail: josemosquera@mail.uniatlantico.edu.co \\ https//:orcid.org/0000-0001-5197-7936 \\ Eslava Pedro \\ Universidad del Magdalena, Santa Marta, Colombia \\ E-mail: pemo2002@gmail.com \\ https//:orcid.org/ 0000-0002-4779-1589
}

\begin{abstract}
The sustainability issues related to food security and use of land, water and energy resources provide impetus to develop treatment technologies that are sensitive to these issues. To advance tropical studies, with an emphasis on sustainability, a small pilot-scale integrated wastewater treatment facility, was designed and built on a small farm in the Sierra Nevada de Santa Marta (Colombia). The system consists of a septic tank, followed in series, by 5 subsurface-flow wetlands, a single surface-flow wetland and a terminal storage lagoon. The efficiency of the pilot plant was studied over a three-year period to evaluate water quality dynamics as a function of hydraulic loading rate, elapsed time and vegetation management. The objective of this study (year II), was to evaluate the comparative efficacy of the treatment units, planted with tomatoes (Lycopersicum sculentum). The results revealed the 5-day biological oxygen demand $\left(\mathrm{BOD}_{5}\right.$ ) and chemical oxygen demand (COD) removal efficiencies were above $41 \%$, coliform bacteria removal was 46 -81\%. No ammonium nitrogen $\left(\mathrm{NH}_{4}{ }^{+}-\mathrm{N}\right)$ removal $(<1 \%)$ and phosphorus removal $\mathrm{PO}_{4}^{-3}-\mathrm{P}$ was of $10 \%$. A relatively high production of tomatoes $\left(730 \mathrm{~g} / \mathrm{m}^{2}\right)$ was obtained in comparison to a traditional crop in a tropical country. These preliminary results will aid in formulating technical design criteria and operational guidelines of constructed wetland technologies for treatment and reuse of domestic wastewater below tropical conditions.
\end{abstract}

Keywords: $\mathrm{COD}, \mathrm{BOD}_{5}$, Nitrification, ortho-phosphate, tomato biomass production.

\section{Resumen}

Los temas de sostenibilidad relacionados con la seguridad alimentaria y el uso de los recursos como tierra, agua y energía, dan impulso al desarrollo de tecnologías de tratamiento sensibles a estos problemas. Para avanzar en los estudios tropicales, con énfasis en la sostenibilidad, se diseñó y construyó una pequeña instalación de tratamiento integrada de aguas residuales a escala piloto en una pequeña granja en la Sierra Nevada de Santa Marta (Colombia). El sistema consta de un tanque séptico, seguido en serie, por 5 humedales de flujo sub superficial, un humedal de flujo superficial y un estanque de almacenamiento final. La eficiencia de la planta piloto fue estudiada durante un período de tres años para evaluar la dinámica de la calidad del agua en función de la carga hidráulica, el tiempo transcurrido y el manejo de la vegetación. El objetivo de este estudio (año II), fue evaluar la eficacia comparativa de las unidades de tratamiento, plantadas con tomates (Lycopersicum sculentum). Los resultados revelaron que la eficiencia de la demanda biológica de oxígeno (DBO5) y la demanda química de oxígeno (DQO) fue superior a 41\% y la eliminación de bacterias coliformes estuvo entre 46 y 81\%. No hubo eliminación de nitrógeno amoniacal $(\mathrm{NH} 4+-\mathrm{N})(<1 \%)$ y la eliminación de fósforo (PO4-3-P) fue del 10\%. Una producción, relativamente alta, de tomates $\left(730 \mathrm{~g} / \mathrm{m}^{2}\right)$ fue obtenida en comparación con un cultivo tradicional en un país tropical. Estos resultados preliminares ayudarán a formular criterios técnicos de diseño y directrices operacionales de tecnologías de humedales construidas para el tratamiento y la reutilización de aguas residuales domésticas bajo condiciones tropicales.

Descriptores: $\mathrm{DQO}, \mathrm{DBO}_{5}$, Nitrificación, orfosfatos, producción de biomasa de tomates. 


\section{INTRODUCTION}

Several different Constructed Wetland (CW) technologies have been deployed and evaluated in Europe and the United States for decentralized treatment of domestic wastewater (Vymazal \& Kröpfelová, 2008; Kadlec \& Wallace, 2009). Despite their recognized environmental benefits and low capital and operating costs, these same CW technologies have been implemented only infrequently in Latin America or on an experimental basis (Torres et al., 2017; Burgos et al.,2017; Caselles-Osorio et al., 2017).

Among, current wastewater treatment technologies, $\mathrm{CW}$ technology is considered as an eco-friendly, low cost technology with some distinct advantages such as; low operation and maintenance cost, as well as provide aesthetic value, generate usable plant biomass, and help support wildlife habitat (Sehar et al., 2014).

Until now most wastewater treatment technologies, including CWs, have been designed and operated to optimize removal of organic contaminants, pathogens and fertilizer nutrients based on mandated effluent discharge standards (Vymazal, 2014). Moreover, alternative forms of wastewater treatment are often needed, as centralized treatment is not always an economical option. This is especially the case in rural and remote regions in developing countries ( $\mathrm{Wu}$ et al., 2016). In Central and South America, discharge standards are not mandated or enforced and as a result sanitary wastewater is often discharged via straight pipe to receiving streams, where they degrade pristine freshwater resources, pollute highly productive estuaries, and exacerbate human health issues. However, in various communities and economic sectors of some countries like Mexico, there are applications of new technologies for wastewater treatment throughout the country (Noyola, 2013; De Anda, 2017).

The re-use of wastewater in agriculture is gaining wider acceptance in many parts of the world (Gatta et al., 2015). In fact, the World Health Organization (WHO, 2006) considers that wastewater in agriculture is a legitimate method of combining water and recycled nutrients, but recommends it should be done safely to maximize public health gains and environmental benefits. Domestic wastewater is potentially rich in nutrients and has traditionally been used as an important source of fertilizers for either agriculture or aquaculture. Yet, many of the advanced wastewater treatment technologies in use today, in many countries discharge treated wastewater to receiving streams with little regard for reclamation of residual nutrients or water reuse. Reused wastewater for irrigation is considered to be a ma- jor resource of nutrients in many parts of the world (Boyden and Rababah, 1996). Cirelli et al. (2012) affirm that under controlled conditions, treated wastewater can be used as an additional water resource to increase the eggplant and tomato production in water-scarce environments. Similarly, García-Pérez et al. (2014) assure that nutrient recovery through the direct use of sewage as fertilizer and water reuse is feasible to have a crop of sunflowers (Helianthus annuus L.).

Population growth, urbanization, migration and industrialization, along with increases in production and consumption, have generated ever-increasing demands for freshwater resources causing critical and inter-related problems linked to food security and sustainable use of land, water and energy resources (WWAP, 2015). For example, there is already intense competition for water among domestic, industrial, and agricultural uses (FAO, 2011).

Given that fertilizer nutrients and most forms of energy are expensive and world prices are escalating, there is strong impetus to develop energy-efficient wastewater treatment systems in which irrigation and reuse of nutrient-rich water will be utilized. In this decentralized paradigm, it is envisioned that treated wastewater will not be discharged to water bodies as in the past, but will instead be reused judiciously to culture valuable crops onsite, or to irrigate communal gardens, pastures, and tree farms (Nelson et al., 2008). These actions will reduce pollution caused by discharge of treated and untreated wastewater to receiving streams, make valuable use of water and residual nutrients, help to recharge depleted groundwater resources, and serve as a potential source of food and income for urban and rural residents.

Taking the above into account, the aim of this study was to evaluate integrated $\mathrm{CW}$ technologies for treating domestic wastewater while producing a crop of tomatoes (Lycopersicum sculentum) and analyze removal efficiency of dissolved organic matter and nitrogenous compounds from domestic wastewater by subsurface flow CWs during two years.

\section{MATERIALS AND METHODS}

\section{Study location and Pilot plant design}

During March and April of 2008, a small pilot-scale integrated CW wastewater treatment facility was designed, built and put into operation at the Biological Reserve CAOBA, which is located $15 \mathrm{~km}$ from the city of Santa Marta (Colombia), in the Manzanares river basin, a warm region, which is characterized by a complex 
mosaic of habitats and very high levels of biodiversity. The design of this integrated system was based in part on in-depth studies of shallow horizontal subsurfaceflow wetlands, HSSF (Caselles \& García, 2006; 2007). The systems provided primary and secondary wastewater treatment for 6 people. The system operated in serial flow (Figure 1), and consists of a $2.6 \mathrm{~m}^{3}$ sedimentation tank for primary clarification, followed by a series of 5 subsurface-flow wetland cells $(1 \mathrm{~m} \times 1 \mathrm{~m} \times$ $0.5 \mathrm{~m})$, a single surface-flow wetland $(2 \mathrm{~m} \times 0.9 \mathrm{~m} \times 0.5 \mathrm{~m})$, and a lagoon reservoir $(1 \times 0.9 \times 0.5)$ polishing of the wastewater and water reuse options (irrigation). The lagoon provided an area for culture of native floating plants and nutrient polishing. The multicell design enabled frequent redistribution of flow to mitigate short-circuiting and to enable periodic removal of sludge from cells 1 and 2 .

Multiple cell designs with appropriate plumbing also allow for bypassing influent cells to facilitate periodic removal of sludge. The clarifier and cells were constructed of hollow cement blocks and sealed with commercial epoxy paint. Each of the subsurface-flow cells were backfilled to a depth of $0.5 \mathrm{~m}$ with screened $10 \mathrm{~mm}$ river gravel harvested from the nearby river. The wetland system was backfilled to a depth of $0.1 \mathrm{~m}$ with river's sand to facilitate rooting of aquatic plants. Plastic standpipe distribution headers at the entrance and exit of each cell facilitated wastewater distribution and maintenance of water level at approximately $0.4 \mathrm{~m}$ depth. In addition, each of cells had slotted vertical plastic pipes installed at strategic locations to allow for in situ measurements and collecting of discrete whole column water samples

Influent wastewater flow rates (L/minute), were estimated using the bucket and stop watch method at one to two hour intervals during daylight hours. It is envisioned that integrated systems such as portrayed in Figure 1 can be planted with adapted vegetable crops, such as tomatoes, and that treated wastewater can be stored in the reservoir and reused as toilet flush water or nutrient rich water for irrigating adjacent crop lands, fish ponds or gardens. These objectives are similar to those as described for high diversity wastewater gardens and irrigated ecoscopes (Nelson et al., 2008).

\section{Planting tomatoes (Lycopersicum sculentum)}

Seeds of tomatoes were germinated in culture flats and grown for 30 days prior to being transplanted into the treatment system. At the time of transplanting, the plants ranged from $10-15 \mathrm{~cm}$ high and were planted on $20 \mathrm{~cm}$. It should be noted that the first treatment cell in the series was not planted due to severe organic clogging. After 94 days of culture, the tomato biomass, including roots, shoots and fruit were harvested in each cell and processed. Harvested tomato fruits were stored in a cardboard box and transferred to laboratory. Two samples of fruit from each treatment cell were rinsed in dechlorinated tap water and the surface and flesh analyzed for coliform bacteria. The remaining tomatoes were weighed in Ohaus TR6RS balance for total biomass calculations.

\section{Pilot Plant PERformanCE MONITORING}

Water quality monitoring was carried out between October of 2009 and May of 2010. During the period December/09 to March/10, tomatoes were cultivated in the treatment cells. During the study, four (4) water samples were collected from each of the 5 treatment cells

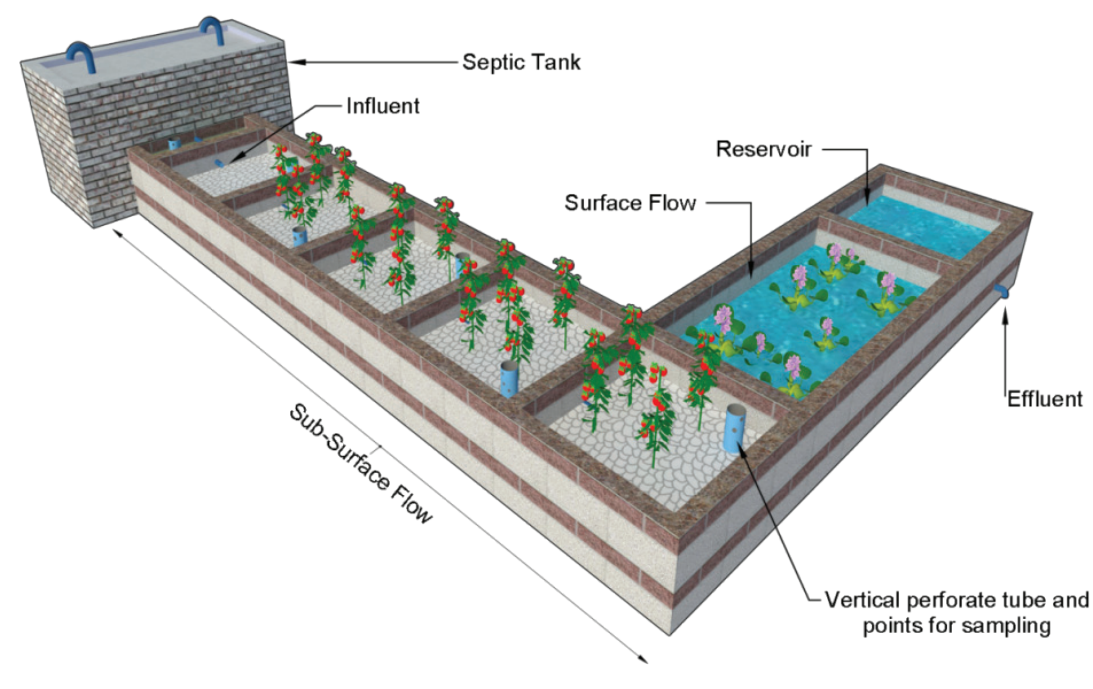

Figure 1. Schematic representation of the pilot plant. Note both wetlands types and a terminal holding reservoir for water reuse options. The sampling points where put in the corner of each cell, assuming the same possibility to examination the wastewater quality 
and four of influent and effluent. The average values were reported. All samples were preserved in an insulated cooler and temperatures were maintained at near $5^{\circ} \mathrm{C}$. Subsequently, and within 24 hours, the samples were analyzed for organic matter $\left(\mathrm{COD}, \mathrm{BOD}_{5}\right)$, ammonium nitrogen $\left(\mathrm{NH}^{4+}-\mathrm{N}\right)$, nitrate nitrogen $\left(\mathrm{NO}_{3}^{-}-\mathrm{N}\right)$, nitrite nitrogen $\left(\mathrm{NO}_{2}^{-}-\mathrm{N}\right)$ and ortho-phosphate $\left(\mathrm{PO}_{4}^{-3}-\mathrm{P}\right)$ using methods as described in (APHA-AWWA-WEF, 2005). Water temperature, dissolved oxygen (DO), $\mathrm{pH}$ and conductivity measurements were obtained by monitoring the water within the vertical perforated PVC tubes (Figure 1). Measurements were taken at the midpoint of the water depth and water temperature, conductivity, $\mathrm{pH}$ and DO measurements were recorded with WTW 315i Set probes. Paired comparisons of inlet and outlet concentrations for each treatment cell were evaluated for COD, $\mathrm{BOD}_{5},\left(\mathrm{PO}_{4}^{-3}-\mathrm{P}\right),\left(\mathrm{NO}_{3}^{-}-\mathrm{N}\right),\left(\mathrm{NO}_{2}^{-}-\mathrm{N}\right)$ and $\left(\mathrm{PO}_{4}^{-3}-\mathrm{P}\right)$.

MICROBIOLOGICAL EXAMINATION FOR TOTAL COLIFORM (TC) AND FECAL COLIFORM (FC),

Samples of wastewater were collected in labeled plastic bottles, placed in a cooler and transported directly to the laboratory where they were stored under refrigeration. The samples were analyzed within $24 \mathrm{~h}$ of collection for the presence of coliform bacteria group (total and faecal coliform) using the multiple-tube fermentation technique (APHA-AWWA-WEF, 2005).

\section{ResulTS AND DISCUSION}

Septic tank effluent can be a strong pollutant, but it can also be a rich and valuable source of organic carbon, total nitrogen (39-82 mg/L), phosphorus (11-21 mg/L), and other essential micro nutrients (Boom, et al., 2008; EPA, 2002; Ferreira et al., 2007). Household wastewater flows used in this study ranged from 423.4 to 1102.3 $\mathrm{L} / \mathrm{d}$. Higher flows were recorded in the early morning and late afternoon hours. Daily flow averaged 832.2 L/ day $(138 \mathrm{~L} /$ person/day), which is within the range of Minimum and maximum net endowment reported in Colombia (RAS, 2000). Assuming $40 \%$ void space of the gravel substrate and 0.4 meters depth, total water volume (excluding the septic tank), totaled approximately $1.7 \mathrm{~m}^{3}$. Therefore, the calculated hydraulic retention time (HRT) was approximately 1.8 days, which is significantly less than conventional recommendations of four to seven days (Kadlec \& Wallace, 2009). The organic loading rate averaged $15.3 \mathrm{~g} \mathrm{BOD} / \mathrm{m}^{2} . \mathrm{d}$ and was also relatively high when compared to recommended rates of 4-8 $\mathrm{gBOD}_{5} / \mathrm{m}^{2} . \mathrm{d}(\mathrm{EPA}, 2000$; Burgos et al., 2017).
The high hydraulic and organic loading rates used in this study proved to be land conserving, but eventually provided challenges in year II related to cell clogging and short-circuiting.

\section{Water Quality Dynamics}

Tables 1 and 2 and Figure 2 provide summary information related to design criteria, water quality and treatment dynamics. Anoxic / anaerobic conditions prevailed in all treatment cells during the study, as evidenced by high $\mathrm{NH}_{4}{ }^{+} \mathrm{N}$ concentrations $(>30 \mathrm{mg} / \mathrm{L})$ and low DO conditions $(<0.2 \mathrm{mg} / \mathrm{L})$. High hydraulic and organic loading rates encouraged high respiration rates leading to anoxic conditions, poor nitrification and no a $\mathrm{NH}_{4}^{+}$-N removal (Table 2). Chronically low DO concentrations and low nitrification rates have been commonly reported for horizontal sub surface flow systems (EPA, 2002; Zhang et al., 2015). Where required, enhanced rates of nitrification and denitrification can be achieved in SSF wetlands by decreasing the depth of the system (Garcia et al., 2014), although it decreases the HRT. However, these design changes often require additional land and capital expenses which may not be justified (EPA, 2002). Poor removal of phosphorus during the second year was also evident (Figure 2), and was most likely related to rapid saturation of gravel microsites (Drizo et al., 1999). The stable tropical temperature regime observed in this study (near $26^{\circ} \mathrm{C}$ ), was viewed as being beneficial as it provided year-round opportunities for plant production (Trang et al., 2010). pH values were relatively stable throughout the system, and always less than 7 which helped to minimize losses of ammonia to volatilization. Electrical conductivity values increased progressively throughout the system, probably due to high rates of evapotranspiration and release of nutrients and elements via organic mineralization (Coleman et al., 2001) Scirpus validus L., and Typha latifolia L.. The $\mathrm{pH}$ and electrical conductivity values range within Colombian environmental standards for agricultural wastewater (Resolution 1207 of 2014).

Influent $\mathrm{COD}$ concentrations ( $326 \mathrm{mg} / \mathrm{L} \pm 176$ ), $\mathrm{BOD}_{5}$ $(124 \mathrm{mg} / \mathrm{L} \pm 33)$, and nutrients were within the ranges reported for septic tank effluents (Crites \& Tchobanoglous, 1998; EPA, 2000). COD and $\mathrm{BOD}_{5}$ removal efficiency were modest and progressive throughout the system (Figure 2) and averaged 42 and $41 \%$ respectively. These levels of removal are low for the tropics as compared to other studies in which values ranged from 54 to $85 \%$ ( Machado, et al., 2016; Caselles et al., 2017) since they can remove a broad range of contaminants 
Table 1. Average conditions observed for the pilot-scale system during eight months of monitoring. Average values for horizontal subsurface-flow wetlands (SSF) for the period Oct/09 to May/10. The standard deviation is shown in brackets, $N=8$

\begin{tabular}{|c|c|c|c|c|c|c|c|}
\hline & $\begin{array}{c}\text { Influent } \\
\text { (Septic tank) }\end{array}$ & Cell 1 & Cell 2 & Cell 3 & Cell 4 & Cell 5 & $\begin{array}{c}\text { Effluent } \\
\text { (SF-Reservoir) }\end{array}$ \\
\hline D.O.(mg/L) & $\begin{array}{c}0.15 \\
(0.16)\end{array}$ & $\begin{array}{c}0.15 \\
(0.17)\end{array}$ & $\begin{array}{c}0.12 \\
(0.12)\end{array}$ & $\begin{array}{c}0.12 \\
0.09)\end{array}$ & $\begin{array}{c}0.18 \\
(0.19)\end{array}$ & $\begin{array}{c}0.14 \\
(0.17)\end{array}$ & $\begin{array}{c}0.19 \\
(0.28)\end{array}$ \\
\hline Temp. (C) & $\begin{array}{l}25.8 \\
(1.6)\end{array}$ & $\begin{array}{l}25.6 \\
(1.9)\end{array}$ & $\begin{array}{l}25.5 \\
(1.6)\end{array}$ & $\begin{array}{l}25.4 \\
(1.0)\end{array}$ & $\begin{array}{l}25.3 \\
(1.4)\end{array}$ & $\begin{array}{l}26.2 \\
(2.1)\end{array}$ & $\begin{array}{l}25.8 \\
(1.6)\end{array}$ \\
\hline $\mathrm{pH}$ & $\begin{array}{c}6.5 \\
(0.2)\end{array}$ & $\begin{array}{c}6.5 \\
(0.2)\end{array}$ & $\begin{array}{c}6.6 \\
(0.2)\end{array}$ & $\begin{array}{c}6.5 \\
(0.2)\end{array}$ & $\begin{array}{c}6.6 \\
(0.2)\end{array}$ & $\begin{array}{l}6.7 \\
(0.1)\end{array}$ & $\begin{array}{c}6.7 \\
(0.1)\end{array}$ \\
\hline Conductivity, $\mu \mathrm{S} / \mathrm{cm}$ & $\begin{array}{l}330.8 \\
(22.6)\end{array}$ & $\begin{array}{l}341.8 \\
(37.5)\end{array}$ & $\begin{array}{l}356.8 \\
(20.0)\end{array}$ & $\begin{array}{l}361.0 \\
(26.2)\end{array}$ & $\begin{array}{l}363,5 \\
(21.5)\end{array}$ & $\begin{array}{l}376,9 \\
(15,6)\end{array}$ & $\begin{array}{l}378,8 \\
(22,0)\end{array}$ \\
\hline${ }^{1}$ Flow $\mathrm{m}^{3} / \mathrm{d}$ & $0.59(0.44)$ & & & & & & \\
\hline $\begin{array}{l}{ }^{2} \text { Applied organic loading rate } \\
\qquad\left(\mathrm{g} / \mathrm{m}^{2} / \text { day }\right)\end{array}$ & \multicolumn{7}{|c|}{$15.3 \mathrm{~g} \mathrm{BOD}_{5}$} \\
\hline $\begin{array}{c}{ }^{3} \text { Nominal Hydraulic Retention } \\
\text { Time (HRT) in hours }\end{array}$ & 105 & 8.1 & 8.1 & 8.1 & 8.1 & 8.1 & 18.3 \\
\hline \multicolumn{8}{|c|}{$\begin{array}{l}\text {. Does not account for losses due to evapotranspiration } \\
\text {. Organic loading rate is calculated as organic load / total surface area of pilot-scale system }\left(7.7 \mathrm{~m}^{2}\right) \\
3 \text {. HRT values (hours), for septic tank, SSF wetlands, surface flow wetland and lagoon-reservoir respectively } \\
\text { Table } 2 \text {. Concentration averages (mg/L), standard deviations (in brackets) and mean removal efficiencies } \\
\text { of the COD, BOD }{ }_{5} \text {, ammonium, nitrate, nitrite and ortho-phosphates in the pilot plant in Santa Marta, Colombia } \\
\text { four times by month during } 8 \text { months. Total and faecal coliform bacteria are expressed in MPN/100 ml. }(\mathrm{N}=32 \text { ) }\end{array}$} \\
\hline \multicolumn{2}{|c|}{ Variables } & \multicolumn{2}{|c|}{ Influent } & Effluent & \multicolumn{2}{|c|}{$\begin{array}{c}\text { \% Total removal } \\
\text { (SF-Reservoir) }\end{array}$} & \\
\hline \multicolumn{2}{|l|}{ COD } & \multicolumn{2}{|c|}{$326(176)$} & $189(155)$ & \multicolumn{3}{|c|}{42} \\
\hline \multicolumn{2}{|l|}{$\mathrm{BOD}_{5}$} & \multicolumn{2}{|c|}{$124(33)$} & $73(32)$ & \multicolumn{3}{|c|}{41} \\
\hline \multicolumn{2}{|l|}{ Ammonium } & \multicolumn{2}{|c|}{$30(26)$} & $32(21)$ & \multicolumn{3}{|c|}{-} \\
\hline \multicolumn{2}{|l|}{ Nitrate } & \multicolumn{2}{|c|}{$3.0(3.6)$} & $1.6(1.0)$ & \multicolumn{3}{|c|}{46} \\
\hline \multicolumn{2}{|l|}{ Nitrite } & \multicolumn{2}{|c|}{$2.8(2.4)$} & $2.5(2.4)$ & \multicolumn{3}{|c|}{10} \\
\hline \multicolumn{2}{|c|}{ Ortho-phosphate } & \multicolumn{2}{|c|}{$6.7(2.5)$} & $5.9(2.1)$ & \multicolumn{3}{|c|}{10} \\
\hline \multicolumn{2}{|c|}{ Total Coliforms, NMP/100 ml } & \multicolumn{2}{|c|}{$7406(1980)$} & $1382(471)$ & \multicolumn{3}{|c|}{81} \\
\hline \multicolumn{2}{|c|}{ Faecal Coliforms, NMP/100 ml } & \multicolumn{2}{|c|}{$365(125)$} & $198(69)$ & \multicolumn{3}{|c|}{46} \\
\hline
\end{tabular}

by a combination of physical, chemical and biological processes with a low cost. Therefore, CWs can be successfully applied for decentralized wastewater treatment in regions with low population density and/ or with large land availability as Brazil. The present work provides a review of thirty nine studies developed on CWs implemented in Brazil to remove wastewater contaminants. Brazil current sanitation data is also considered to evaluate the potential role of CWs as decentralized wastewater treatment. Performance of CWs was evaluated according to (i. It is inferred that the modest removal rates in this study were influenced by the relatively high hydraulic and organic loading rates. $\mathrm{NH}_{4}{ }^{+}-\mathrm{N}$ and $\mathrm{PO}_{4}^{-3}-\mathrm{P}$ removal within the system (Fi- gure 2) were very low and in fact ammonium concentrations increased within the system. This behavior is not uncommon in subsurface-flow wetlands (EPA, 2000) and can be explained on the basis of poor nitrification due to anoxic conditions, while the addition of new ammonium in cells 4 and 5 resulted from mineralization of stored organic matter. During year I, Caselles et al. (2008) reported moderate levels of nitrification and $\mathrm{NH}_{4}^{+}-\mathrm{N}$ removal, but this was during system start up and before anoxic conditions and cell clogging became chronic. $\left(\mathrm{NO}_{3}{ }^{-}-\mathrm{N}\right)$ and $\left(\mathrm{NO}_{2}^{-}-\mathrm{N}\right)$ concentrations remained less than $3 \mathrm{mg} / \mathrm{L}$, and were probably controlled by a lack of nitrification and near optimum conditions for denitrification. 
Nitrate and coliform effluent concentration values were low and in compliance with Colombian environmental standards for agricultural wastewater. (Resolution 1207 of 2017). Removal of coliform bacteria was progressive throughout the system (Figure 2), and averaged 46 and $81 \%$ for fecal and total coliforms, respectively. It is anticipated that the short hydraulic retention time ( $<2$ days), did not allow for higher coliform removal rates.

It is know that in small human settlements, the relationship between mean flows and peak flows is higher than in medium and big cities (Crites \& Tchobanoglous, 1998). These higher flow variations affected the organic load variations and pollutants concentrations, as COD and nitrogen species (Table 2).

Although the process of clogging was not monitored, it was especially evident in cell 1 where water surfaced and caused short-circuiting. Eventually, during the course of the study, cell 1 was cleaned out in Dec. 2009 and returned to service. Clogging is a chronic problem in SSFW ( Knowles et al., 2011; Corbella et al., 2016) leading to surface ponding, odors, mosquitoes and short circuiting. Mechanical and non-invasive techniques have been evaluated for remediating clogged cells
(Pedescoll et al., 2012), and additional studies will be required to validate cost-effective remediation strategies. Note however, that several studies have reported no loss of treatment efficacy, even with severe clogging (Drizo et al., 1999; Caselles \& García, 2007; Aiello et al., 2016;). In retrospect, it is surmised that clogging phenomena could have been avoided by installing a shallow surface-flow wetland as the first treatment cell in the series. This would have allowed much of the particulate organic matter in the septic tank effluent to settle in the surface-flow wetland, thus removing some of the particulate load, and delaying clogging in the following sub-surface flow wetland cells (Behrends et al., 2007)

\section{TOMATOES PRODUCTION}

Although the influence of tomatoes plants on nutrient removal was not representative, this does not detract from the potential for producing valuable crops that are adapted to saturated conditions. It is possible that growth in waterlogged soils is achieved by exploiting the availability of nutrients. Traditionally tomato cultivation reaches is completed in three months (Ricardo et al., 2013). Tomatoes were cultivated in cells 2 to 5, and
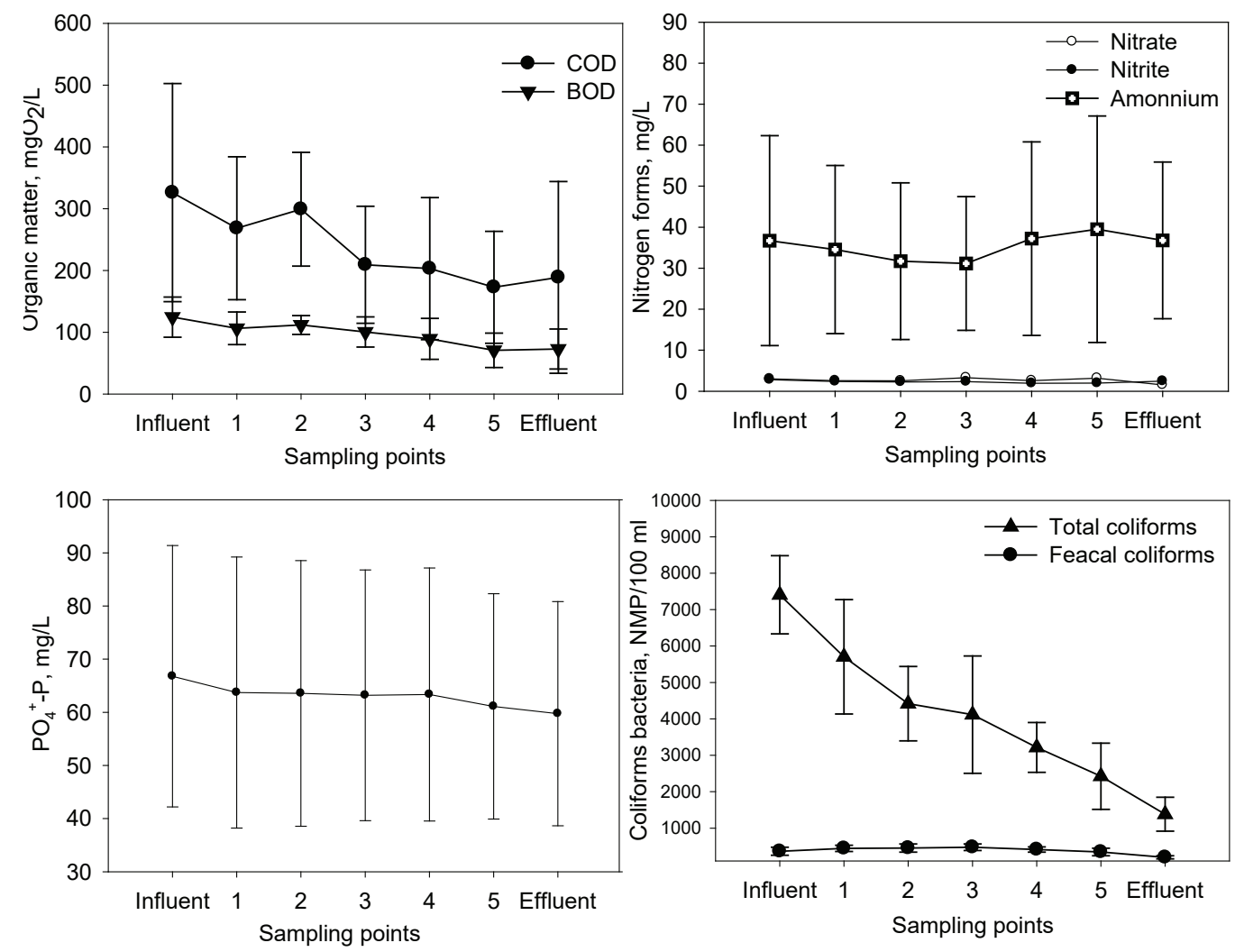

Figure 2. Spatial treatment of wastewater contaminants in pilot plant in Santa Marta, Colombia 
resulted in production of $2.2 \mathrm{~kg}$ of tomatoes fruit (Figure 3), it is $0.73 \mathrm{Kg} / \mathrm{m}^{2}$. Annual production of tomatoes in a traditional crop in one tropical country like Colombia, is on average, $3.7 \mathrm{~kg} / \mathrm{m}^{2}$ (Agronet, 2014). Cirelli et al., (2012), reported a maximum tomato crop of $8.97 \mathrm{Kg} / \mathrm{m}^{2}$ during a two-year trial of tertiary-treated municipal wastewater use in tomato crop irrigation. Our results are lower than those of Cirelli et al., (2012). We produced tomatoes in just four months.

Although production in the experiment of this study is lower respect a traditional crop, the hydroponic conditions could affect the total production. Growth performance and crop yield of tomato plants were stu- died by Rana et al. (2011) with different wastewater concentrations. These authors reported that maximum crop production was recorded at $100 \%$ wastewater. The Cell 3 production was nil, probably due to not enough oxygen to nitrification of ammonia and $\left(\mathrm{NH}^{4+}-\mathrm{N}\right)$ high levels $(>30 \mathrm{mg} / \mathrm{L})$, which could be toxic for tomatoes (Martínez et al., 2013). Additionally, tomatoes prefer nitrate as a source of nitrogen and may explain the zero growth of tomatoes in cell 3 where the plants were short and thin and produced no fruits (Figure 4).

Soil conditions in HSSF constructed wetlands can limit use of terrestrial plants, like tomatoes. Nevertheless, several studies have shown that some plants adopt
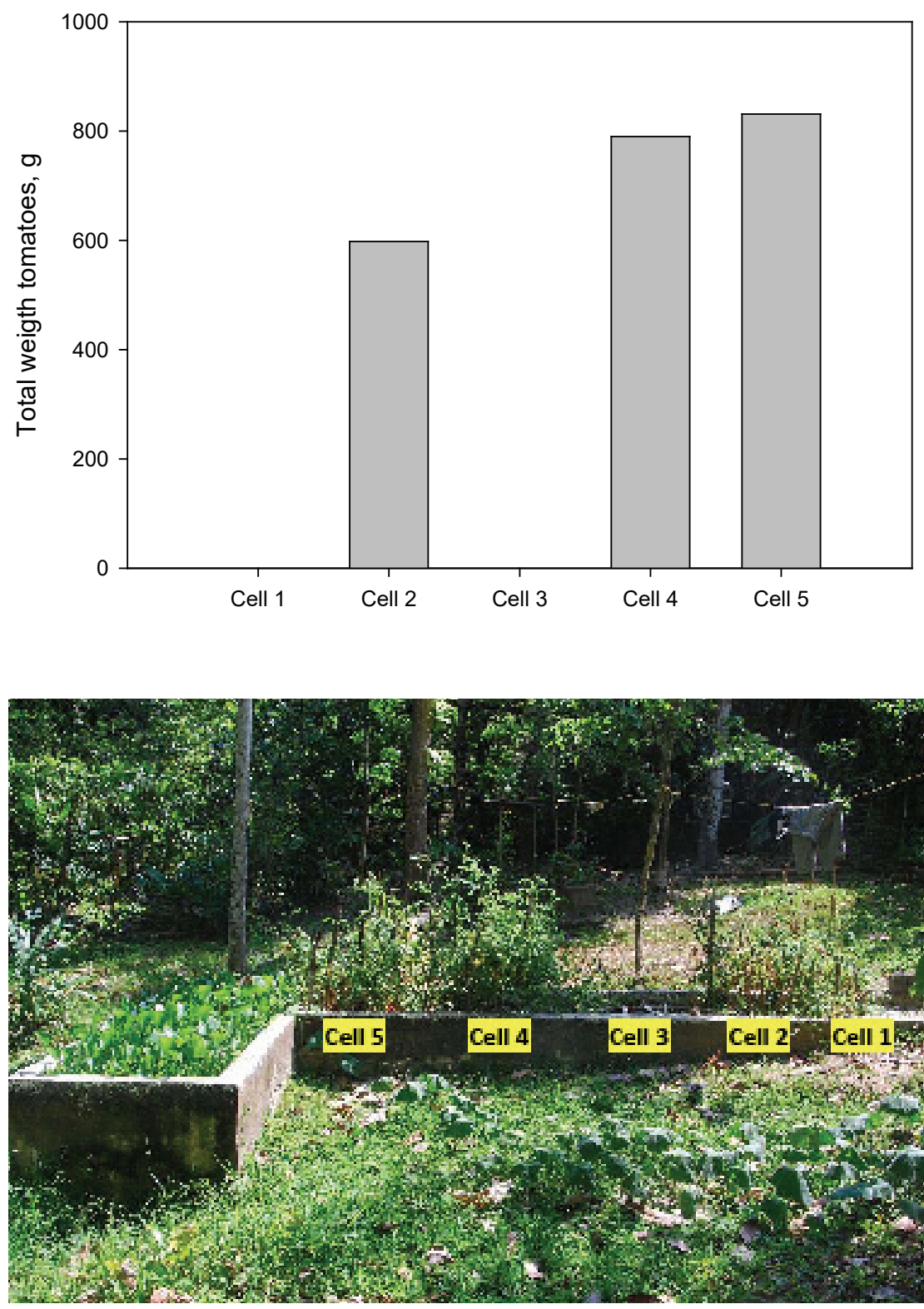

Figure 3. Total fresh weight of tomatoes fruit $(\mathrm{g} / \mathrm{cell})$ in SSF CW. Note that Cell 1 was not planted due to clogging and cell 3 productions were negligible for unknown reasons
Figure 4. Picture of the pilot plant with planted tomatoes. Note growth of tomatoes in most cells except cell 3 
strategies to grow in stress conditions (Hough et al., 2015). One the major biological consequences of soil flooding is oxygen deficiency. According with Lin et al. (2004), most tomato varieties are not able to tolerate flooding stress, but they have evolved a complex antioxidative defense system composed of both antioxidant enzymes and metabolites to survive oxidative stress. Then, it may be possible to utilize wastewater treatment in $\mathrm{CW}$ for the production of crop tomatoes.

Testing tomatoes for coliform bacteria indicated that there was negligible contamination of tomatoes fruits and suggests that with care, treated wastewater can be used for cultivating and drip-irrigating vegetable crops. Al-Lahham et al. (2003) reported similar results in tomatoes drip irrigated with treated wastewater, but with contamination on the tomato skin. These authors suggested that the treated wastewater can be used as an alternative for irrigation, and that the tomatoes can be eaten after cooking.

Finally, the experiments showed that treating wastewater with $\mathrm{CW}$ could become a profitable business in rural areas with little space limitation; instead, the occupied surface could generate income by tomatoes production.

\section{Conclusions}

The concept of using natural treatment systems and irrigation of treated wastewater to enhance ecosystem sustainability is not novel (Gatta et al., 2015). Nonetheless, the system deployed in the present study deviated significantly from conventional wastewater treatment goals, which continue to emphasize maximizing removal of organic matter and nutrients with little or no regard for reuse of water and residual nutrients. This study was conducted to evaluate the potential for using integrated constructed wetland technologies for sustainably treating sanitary wastewater while conserving valuable fertilizer nutrients and producing a tomato crop. It is further proposed and envisioned that these nutrient-rich effluents can be reused to irrigate gardens, landscape plantings and various other high-value crops. During year II of this study, the integrated treatment system provided moderate removal of COD and $\mathrm{BOD}_{5}(\approx 43 \%)$ and coliform bacteria $(>45 \%)$. The system effectively conserved fertilizer nutrients, which we found to be a positive attribute in terms of potential for sustainable irrigation and crop production. The integrated system produced a crop of tomatoes that were eaten by the farm residents who found the tomatoes to be tasty and with no ill effects. With respect to sustainability issues, we surmise that use of residual organic matter and nutrients may be cost effective for on-site irrigated systems. It is concluded that production of tomatoes or other valuable crops using treated wastewater can be sustainable with respect to reducing pollution, improving water quality and augmenting the diet and income of farm residents.

\section{ACKNOWLedgements}

The authors wish to express appreciation to the Water Center Study of the University of the Atlantic for the economic support. We also want to thank to Eberhard Wedler, Ph D, of the Biological Reserve CAOBA for his technical support and advice. Finally, we want to express appreciation to Yorcelis Cruz, Ph D, for their generous donation of reagents, which were used for coliform analyses and water quality.

\section{RefERENCES}

Agronet. MinAgrigultura. (2014). Área Sembrada y Área Cosechada del Cultivo de tomate 2007-2014. http://www.agronet. gov.co/Documents/Arveja.pdf

Aiello, R., Bagarello, V., Barbagallo, S., Iovino, M., Marzo, A., Toscano, A. (2016). Evaluation of clogging in full-scale subsurface flow constructed wetlands. Ecological Engineering, 95, 505-513. https://doi.org/10.1016/j.ecoleng.2016.06.113

Al-Lahham, O., El Assi, N.M., Fayyad, M. (2003). Impact of treated wastewater irrigation on quality attributes and contamination of tomato fruit. Agricultural Water Management, 61(1), 51-62. https://doi.org/10.1016/S0378-3774(02)00173-7

APHA-AWWA-WEF. (2005). Standard Methods for the Examination ofWater andWaste-water (21st ed.). Washington, DC: American Public Health Association.

Behrends, L.L., Bailey, E., Jansen, P., Houke, L., Smith, S. (2007). Integrated constructed wetland systems: design, operation, and performance of low-cost decentralized wastewater treatment systems. Water Sciencie and Technologie, 55(7), 155161. https://doi.org/10.2166/wst.2007.140

Boom, S., Huibers, F.P., Van Lier, J.B. (2008). Wastewater irrigation in Jordan: A mismatch in macro nutrient provision. Water Practice and Technology, 3(2), 1-9. https://doi.org/10.2166/ WPT.2008042

Boyden, B.H \& Rababah A.A. (1996). Recycling nutrients from municipal wastewater. Desalination, 106,. 24 1-246.

Burgos, V., Araya, F., Reyes-Contreras, C., Vera, I. y Vidal, G. (2017). Performance of ornamental plants in mesocosm subsurface constructed wetlands under different organic sewage loading. Ecological Engineering, 99, 246-255. https://doi. org/10.1016/j.ecoleng.2016.11.058

Caselles, A., Eslava, P., Palmieri, F. (2008). Assessment of a pilotscale constructed wetland system for treatment of sanitary 
wastewater in Colombia, South America. 81st Annual Water Environment Federation, Technical Exhibition and Conference. (pp. 18-22). Chicago, Ill.

Caselles, A. \& García, J. (2006). Performance of experimental horizontal subsurface flow constructed wetlands fed with dissolved or particulate organic matter. Water Research, 40(19), 3603-3611. https://doi.org/10.1016/j.watres.2006.05.038

Caselles, A. \& García, J. (2007). Impact of different feeding strategies and plant presence on the performance of shallow horizontal subsurface-flow constructed wetlands. Science of the Total Environment, 378(3), 253-262. https://doi.org/10.1016/j. scitotenv.2007.02.031

Caselles, A., Vega, H., Lancheros, J.C., Casierra-Martínez, H.A., Mosquera, J.E. (2017). Horizontal subsurface-flow constructed wetland removal efficiency using Cyperus articulatus L. Ecological Engineering, 99, 479-485. https://doi.org/10.1016/j. ecoleng.2016.11.062

Cirelli, G.L., Consoli, S., Licciardello, F., Aiello, R., Giuffrida, F., Leonardi, C. (2012). Treated municipal wastewater reuse in vegetable production. Agricultural Water Management, 104, 163-170. https://doi.org/10.1016/j.agwat.2011.12.011

Coleman, J., Hench, K., Garbutt, K., Sextone, A., Bissonnette, G., Skousen, J. (2001). Treatment of domestic wastewater by three plant species in constructed wetlands. Water, Air, and Soil Pollution, 128, 283-295. https://doi.org/10.1023/a:1010336703606

Corbella, C., García, J., Puigagut, J. (2016). Microbial fuel cells for clogging assessment in constructed wetlands. Science of the Total Environment, 569-570, 1060-1063. https://doi.org/10.1016/j. scitotenv.2016.06.163

Crites, R. \& Tchobanoglous, G. (1998). Small and decentralized wastewater management systems (McGraw-Hil). New York.

De Anda. (2017). Saneamiento descentralizado y reutilización sustentable de las aguas residuales municipales en México. Sociedad y Ambiente, 5, 14, ISSN: 2007-6576, 119-143.

Drizo, A., Frost, C.A., Grace, J., Smith, K.A. (1999). Physico-chemical screening of phosphate-removing substrates for use in constructed wetland systems. Water Research, 33(17), 35953602. https://doi.org/10.1016/S0043-1354(99)00082-2

EPA. Environmental Pollution Agency. (2002). Onsite W aste w ater $\mathrm{T}$ reatment astew Wastewater Treatment Systems Manual, 71-76.

EPA Environmental Pollution Agency. (2000). Manual Constructed Wetlands Treatment of Municipal Wastewaters Manual Constructed Wetlands Treatment of Municipal Wastewaters. National Risk Management Research Laboratory Office of Research and Development U.S.

FAO. (2011). The state of the world's land and water resources for food and agriculture (SOLAW) Managing systems at risk. Rome and Earthscan, London: The Food and Agriculture Organization of the United Nations and Earthscan.

Ferreira, A., Melfi, A.J., Monteiro, F.A., Montes, C.R., Almeida, V.V. de, Herpin, U. (2007). Treated sewage effluent as a source of water and nitrogen for Tifton 85 bermudagrass. Agricultural Water Management, 87(3), 328-336. https://doi.org/10.1016/j. agwat.2006.08.004

García, A.M. \& Harrison, B.G. (2014). Sunflowers (Helianthus annuus L.) on Top of a Constructed Wetland as an Engineered Ecosystem to Clean Sewage Onsite. Open Journal of Water Pollution and Treatment. 1 (2).

Gatta, G., Libutti, A., Gagliardi, A., Beneduce, L., Brusetti, L., Borruso, Tarantino. E. (2015). Treated agro-industrial wastewater irrigation of tomato crop: Effects on qualitative/quantitative characteristics of production and microbiological properties of the soil. Agricultural Water Management, 149, 33-43. https:// doi.org/10.1016/j.agwat.2014.10.016

Hough, N., Nackley, L.L., Kim, S.H., Ewing, K. (2015). Does plant performance under stress explain divergent life history strategies? The effects of flooding and nutrient stress on two wetland sedges. Aquatic Botany, 120(PB), 151-159. https://doi. org/10.1016/j.aquabot.2014.03.001

Kadlec, R. \& Wallace, S. (2009). Treatment wetlands (2nd ed.). Boca Raton London New York: CRC Press, Taylor \& Francis Group.

Knowles, P., Dotro, G., Nivala, J., García, J. (2011). Clogging in subsurface-flow treatment wetlands: Occurrence and contributing factors. Ecological Engineering, 37(2), 99-112. https:// doi.org/10.1016/j.ecoleng.2010.08.005

Lin, K.H.R., Weng, C.C., Lo, H.F., Chen, J.T. (2004). Study of the root antioxidative system of tomatoes and eggplants under waterlogged conditions. Plant Science, 167(2), 355-365. https:// doi.org/10.1016/j.plantsci.2004.04.004

Machado, A.I., Beretta, M., Fragoso, R., Duarte, E. (2016). Overview of the state of the art of constructed wetlands for decentralized wastewater management in Brazil. Journal of Environmental Management, 187, 560-570. https://doi. org/10.1016/j.jenvman.2016.11.015

Martínez, C., Ghanem, M.E., Albacete, A., Pérez-Alfocea, F. (2013). Response to nitrate/ammonium nutrition of tomato (Solanum lycopersicum L.) plants overexpressing a prokaryotic NH4+dependent asparagine synthetase. Journal of Plant Physiology, 170(7), 676-687. https://doi.org/10.1016/j.jplph.2012.12.011

Ministerio de Desarrollo Economico Dirección. (2000). RAS 2000 Documentación Técnico Normativa del Sector de Agua Potable y Saneamiento Básico. Dirección General de Agua Potable y Saneamiento Básico Documentación.

Ministerio de Ambiente y Desarrollo Sostenible. (2014). Resolución 1207 de 25 de julio de 2014 por la cual se adoptan sipsosicones ralcinads con el reuso del agua residual tratada. Bogotá - Colombia

Nelson, M., Cattin, F., Rajendran, M., Hafouda, L. (2008). Valueadding through creation of high diversity gardens and ecoscapes in subsurface flow constructed wetlands: Case studies in Algeria and Australia of Wastewater Gardens ${ }^{\circledR}$ systems. Proceedings of 11th International Conference on Wetland Sys- 
tems for Water Pollution Control, 344-356. Retrieved from http://www.wastewatergardens.com/pdf/2008_IWAIndia.pdf Noyola, A., Morgan-Sagastume, J.M., Güereca, L.P. (2013). Selección de tecnologías para el tratamiento de aguas residuales municipales. Guía de apoyo para ciudades pequeñas y medianas. México: Instituto de Ingeniería-UNAM , 140 pp

Pedescoll, A., Knowles, P.R., Davies, P., García, J., Puigagut, J. (2012). A comparison of in situ constant and falling head permeameter tests to assess the distribution of clogging within horizontal subsurface flow constructed wetlands. Water, Air, and Soil Pollution, 223(5), 2263-2275. https://doi.org/10.1007/ s11270-011-1021-4

Rana, S., Bag, S.K., Golder, D., Mukherjee Roy, S., Pradhan, C., Jana, B.B. (2011). Reclamation of municipal domestic wastewater by aquaponics of tomato plants. Ecological Engineering, 37(6), 981-988. https://doi.org/10.1016/j. ecoleng.2011.01.009

Sehar, S., Sumera, Naeem, S., Perveen, I., Ali, N., Ahmed, S. (2014). A comparative study of macrophytes influence on wastewater treatment through subsurface flow hybrid constructed wetland. Ecological Engineering, 81, 62-69. https://doi.org/10.1016/j. ecoleng.2015.04.009

Torres, Á.X., Hernández, N.A., Fausto, A.A., Zurita, F. (2017). Evaluación de Tres Sistemas de Humedales Híbridos a Escala Piloto para la Remoción de Nitrógeno. Revista Internacional de Contaminación Ambiental, 33(1), 37-47. https://doi.org/10.20937/ RICA.2017.33.01.03

Trang, D., Konnerup, D., Schierup, H., Huu, N., Tuan, L.A., Brix, H. (2010). Kinetics of pollutant removal from domestic wastewater in a tropical horizontal subsurface flow constructed wetland system : Effects of hydraulic loading rate, 36, 527-535. https://doi.org/10.1016/j.ecoleng.2009.11.022

Vymazal, J. (2014). Constructed wetlands for treatment of industrial wastewaters: A review. Ecological Engineering, 73, 724751. https://doi.org/10.1016/j.ecoleng.2014.09.034

Vymazal, J. \& Kröpfelová, L. (2008). Wastewater Treatment in Constructed Wetlands with Horizontal Sub-Surface Flow. Environmental Pollution, 14. Czech Republic: Springer.

WHO, World Health Organization. (2006). Guidelines for the safe use of wastewater, excreta and greywater / World Health Organization. V. 2. Wastewater use in agriculture. France. 100 p.

Wu, S., Carvalho, P.N., Müller, J.A., Manoj, V.R., Dong, R. (2016). Sanitation in constructed wetlands: A review on the removal of human pathogens and fecal indicators. Science of the Total Environment, 541， 8-22. https://doi.org/10.1016/j.scitotenv.2015.09.047

WWAP (United Nations World Water Assessment Programme). (2015). The United Nations World Water Development Report 2015: Water for a Sustainable World. Paris: UNESCO. https:// doi.org/978-92-3-100071-3

Zhang, D.Q., Jinadasa, K.B.S.N., Gersberg, R.M., Liu, Y., Tan, S.K., $\mathrm{Ng}$, W.J. (2015). Application of constructed wetlands for wastewater treatment in tropical and subtropical regions (20002013). Journal of Environmental Sciences (China), 30, 30-46. https://doi.org/10.1016/j.jes.2014.10.013 